\title{
ПРОЦЕСУАЛЬНІ СТРОКИ ЯК ГАРАНТІЯ ДОТРИМАННЯ ПРАВА НА СВОБОДУ ТА ОСОБИСТУ НЕДОТОРКАНІСТЬ ПД ЧАС КРИМІНАЛЬНОГО ПРОВАДЖЕННЯ
}

\begin{abstract}
КУШНЕРЬОВ Віталій Миколайович - аспірант наукової лабораторії дослідження проблем досудового розслідування Національної академії внутрішніх справ
\end{abstract}

УДК 341.645

DOI:10.32782/NP.2020.2.21

У статті здійснено аналіз національного кримінального процесуального законодавства щзодо визначення прочесуальних строків як гарантї дотримання права на свободу та особисту недоторканість під час кримінального провадження. Визначено, що під кримінальними процесуальними гарантіями необхідно розуміти систему правових засобів та методів, що забезпечують реалізацію процесуальних прав та виконання прочесуальних обов'язків учасниками кримінального провадження. Аргументовано, що під час досудового розслідування чітко визначені часові межі тривалості застосування запобіжних заходів, що обмежують конституиійне право особи на свободу та особисту недоторканість, щзо максимально забезпечує дотримання иъого права в кримінальному провадженні, захищаючи осіб від надмірного, неприпустимого примусу. Автором доведено, що необхідно внести зміни в ч.3 cm.315 та ч. 3331 КПК Украӥни.

Ключові слова: строки, кримінальні процесуальні гарантї, запобіжні заходи, право на свободу та особисту недоторканість.

\section{Вступ}

Євроінтеграція України є одним із пріоритетів внутрішньої та зовнішньої політики держави. Україна тривалий час поглиблює співробітництво в економічній, політичній та правовій сферах 3 країнами-членами EC 3 метою стати повноправним членом Европейського Союзу.

Одним з найголовніших завдань держави є дотримання прав і свобод людини та грома- дянина. Зокрема, це стосується кримінальної процесуальної діяльності правоохоронних органів та судів. Основні права і свободи людини визначено у Конвенції про захист прав людини та основоположних свобод (1950р.), ратифікованої Верховною Радою України 17.07.1997 р. Так, відповідно до ст. 5 Конвенції про захист прав людини та основоположних свобод, кожен має право на свободу та особисту недоторканність. Крім того, кожен, кого заарештовано або затримано $з$ метою до провадження до компетентного судового органу за наявності обгрунтованої підозри у вчиненні особою правопорушення або якщо обгрунтовано вважається необхідним запобігти вчиненню особою правопорушення чи втечі після його вчинення, має негайно постати перед суддею чи іншою посадовою особою, якій закон надає право здійснювати судову владу, і йому має бути забезпечено розгляд справи судом упродовж розумного строку або звільнення під час провадження [6].

Так, аналізуючи судову практику Европейського суду з прав людини, можна стверджувати, що велика кількість скарг надходить 3 приводу довготривалості розгляду справ судами, оскільки при цьому порушується важливий принцип "розумності строків». Дотримання зазначеного принципу дуже важливе для здійснення правосуддя. Право на судовий розгляд справи «в розумні строки» належить до основних прав і свобод людини та громадянина. Затягування провадження є своєрідним порушенням прав i свобод людини та громадянина. 


\section{Кримінальне право, кримінальний процес та криміналістика}

\section{Стан дослідження}

Процесуальні строки в кримінальному судочинстві досліджували такі вчені, як Ю. М. Грошевий, М. М. Міхеєнко, А. М. Москвіч, В. Т. Маляренко, О. В. Капліна, В. В. Назаров, В. Т. Нор, С. В. Слінько, О. В. Шило, А. Д. Удалова та ін.

Метою статті є дослідження процесуальних строків як гарантій дотримання права на свободу та особисту недоторканість під час кримінального провадження

\section{Виклад основного матеріалу}

Відповідно до ст. 3 Конституції України права і свободи людини та їх гарантії визначають зміст і спрямованість діяльності держави. Держава відповідає перед людиною за свою діяльність. Утвердження і забезпечення прав і свобод людини є головним обов'язком держави, і вона гарантує їх дотримання. Це стосується і кримінальної процесуальної діяльності правоохоронних органів, під час якої найбільше обмежуються права і свободи людей.

M. С. Строгович вважав, що процесуальні гарантії у кримінальному судочинстві становлять собою «встановлені законом засоби, за допомогою яких громадяни, які беруть участь у кримінальному процесі, можуть захищати свої права та інтереси» [17, с. 13].

На думку Л. Д. Удалової, процесуальні гарантії - це передбачені кримінальним процесуальним законом засоби забезпечення завдань кримінального судочинства й охорони прав і законних інтересів осіб, які беруть у ньому участь [19, с. 23].

Під процесуальними гарантіями розуміють також встановлені кримінальним процесуальним правом засоби і способи, покликані забезпечувати здійснення прав і обов'язків учасників кримінально-процесуальної діяльності і досягнення мети кримінального судочинства [10, с. 44], а також сукупність встановлених законом правових норм, що забезпечують законний i обгрунтований розгляд кожної кримінальної справи і виконання інших завдань кримінального судочинства, правові засоби, що забезпечують усім суб'єктам кримінальної процесуальної діяльності можливість реально виконувати свої обов'язки та використовувати надані права [4, с. 16-17].

Процесуально-правові гарантії визначають лише як правові засоби, що містяться в нормах та забезпечують усім суб'єктам кримінально-процесуальної діяльності можливість виконувати обов'язки і використовувати надані права [2, с. 39; 1, с. 52] або як визначені процесуальним законом засоби забезпечення ефективного функціонування кримінального процесу [8, с. 23].

Під кримінальними процесуальними гарантіями розуміють ті засоби, що встановлені кримінально-процесуальними нормами для здійснення завдань кримінального судочинства, насамперед захисту прав і законних інтересів осіб, що притягаються до кримінальної відповідальності [3, с. 21].

На думку В. М. Трофименко, кримінальні процесуальні гарантії є частиною правового статусу особи, оскільки за допомогою таких гарантій можна реалізувати права, свободи й обов'язки людини та громадянина. Крім того, як зазначає автор, кримінальні процесуальні гарантії направлені на забезпечення встановленого законом функціонування певного суспільного чи правового інституту $[18$, c. 20].

Отже, під кримінальними процесуальними гарантіями необхідно розуміти систему правових засобів та методів, що забезпечують реалізацію процесуальних прав та виконання процесуальних обов'язків учасниками кримінального провадження[5, с. 15].

Визначивши поняття «кримінальні процесуальні гарантії, необхідно визначити сутність принципу забезпечення права на свободу та особисту недоторканість під час кримінального процесу та визначити, яким чином процесуальні строки є гарантом права на свободу та особисту недоторканість у кримінальному процесі України.

Принцип забезпечення права на свободу та особисту недоторканість, який закріплений у ст. 29 Конституції України, спрямований на забезпечення процесуальних умов, які унеможливлюють порушення прав і свобод осіб, що є учасниками кримінального провадження.

Як зазначає В. I. Маринів, недоторканість особи - це гарантована державою особиста 
Кушнерьов В.М. - Процесуальні строки як гарантія дотримання права на свободу...

свобода і безпека, що полягає в недопущенні, припиненні і покаранні посягань на життя, здоров'я, тілесну недоторканність і статеву свободу, честь і достоїнство, моральну й індивідуальну свободу особи, яка виражається в наданні їй можливості розпоряджатися собою і за своїм бажанням визначати місце перебування[9].

Одним із видів свободи є свобода пересування. Сучасна людина повинна мати можливість вільно пересуватись територією своєї країни. Але інколи під час кримінального провадження виникає необхідність в обмеженні цього права особи, яка підозрюється або обвинувачується у вчиненні злочину. Таке обмеження можливе лише при застосуванні передбачених чинним кримінальним процесуальним законодавством заходів, зокрема заходів забезпечення кримінального провадження (запобіжних заходів).

Відповідно до ст. 29 Конституції України кожному заарештованому чи затриманому має бути невідкладно повідомлено про мотиви арешту чи затримання, роз'яснено його права та надано можливість 3 моменту затримання захищати себе особисто та користуватися правничою допомогою захисника. Аналогічне положення має ч. 2 ст. 5 Европейської конвенції з прав людини.

Відповідно до чинного кримінального процесуального законодавства України обмежити право на свободу та особисту недоторканість можна шляхом затримання особи в порядку, визначеному КПК України, застосування до особи запобіжного заходу у вигляді домашнього арешту чи тримання під вартою.

Відповідно до положень КПК України, законодавець визначає законне затримання (ст. 207 КПК - затримання будь-якою особою правопорушника) та затримання уповноваженою службовою особою (ст. 208 КПК України), при цьому особа (правопорушник) є затриманою з моменту, коли вона силою або через підкорення наказу змушена залишатися поряд із уповноваженою службовою особою чи в приміщенні, визначеному уповноваженою службовою особою. Строк затримання особи без ухвали слідчого судді, суду не може перевищувати сімдесяти двох годин з моменту затримання. Отже, затри- мання особи обмежує право особи на свободу протягом 72 годин, однак відлік цього часу починається з моменту, коли особа силою або через підкорення наказу змушена залишатися поряд із уповноваженою службовою особою чи в приміщенні, визначеному уповноваженою службовою особою. Що стосується законного затримання, то на законодавчому рівні строк такого затримання не визначений. Відповідно до ч. 3 ст. 207 кожен, хто не $є$ уповноваженою службовою особою (особою, якій законом надано право здійснювати затримання) і затримав відповідну особу в порядку, передбаченому КПК, зобов’язаний негайно доставити ії до уповноваженої службової особи або негайно повідомити уповноважену службову особу про затримання та місцезнаходження особи, яка підозрюється у вчиненні кримінального правопорушення. Отже, затримана особа може бути обмежена в свободі пересування на невизначений законом строк, а недотримання принципу забезпечення права на свободу та особисту недоторканість є порушенням не тільки норм чинного кримінального процесуального законодавства, а й, в окремих випадках, кримінального законодавства.

У такому випадку необхідно враховувати положення ч. 2 ст. 12 КПК, яка передбачає, що у разі позбавлення свободи затриманій особі повинно бути у найкоротший строк, але не пізніше 72 годин з моменту затримання вручене вмотивоване судове рішення про тримання під вартою або затримана особа повинна бути негайно звільнена. Момент затримання в такому випадку треба рахувати 3 часу законного затримання, а не 3 моменту доставлення до уповноваженої службової особи.

Що ж стосується виконання ст. 5 Европейської конвенції з прав людини в частині негайного доставлення затриманої особи до суду, то відповідно до ч. 2 ст. 211 КПК України затримана без ухвали слідчого судді, суду особа не пізніше шістдесяти годин з моменту затримання повинна бути звільнена або доставлена до суду для розгляду клопотання про обрання щодо неї запобіжного заходу.

Ще одним обмеженням права особи на свободу та особисту недоторканість є запо- 


\section{Кримінальне право, кримінальний процес та криміналістика}

біжний захід у вигляді домашнього арешту та тримання під вартою.

Так, відповідно до ст. 181 КПК України домашній арешт полягає в забороні підозрюваному, обвинуваченому залишати житло цілодобово або у певний період доби, що, у свою чергу обмежує права особи на свободу та особисту недоторканість [7]. Для захисту цього права чинне кримінальне процесуальне законодавство визначило певні обмеження в тривалості зазначеного запобіжного заходу. Так, відповідно до ст. 181 КПК України строк дії ухвали слідчого судді про тримання особи під домашнім арештом не може перевищувати двох місяців, що становить загальний термін проведення досудового розслідування після оголошення особі підозри про вчинення злочину. Проте строк тримання особи під домашнім арештом може бути продовжений у межах строку досудового розслідування, але сукупний строк тримання особи під домашнім арештом під час досудового розслідування не може перевищувати шести місяців. По закінченню цього строку ухвала про застосування запобіжного заходу у вигляді домашнього арешту припиняе свою дію і запобіжний захід вважається скасованим [7].

Ще одним запобіжним заходом, який обмежує права особи на свободу та особисту недоторканість є тримання під вартою. Відповідно до ст. 184 КПК України запобіжний захід у вигляді тримання під вартою не може бути застосований, окрім як: 1) до особи, яка підозрюється або обвинувачується у вчиненні злочину, за який законом передбачено основне покарання у виді штрафу в розмірі понад три тисячі неоподатковуваних мінімумів доходів громадян, - особливо у разі, якщо прокурором, крім наявності підстав, передбачених ст. 177 КПК України, буде доведено, що підозрюваний, обвинувачений не виконав обов'язки, покладені на нього при застосуванні іншого, раніше обраного запобіжного заходу, або не виконав у встановленому порядку вимог щодо внесення коштів як застави та надання документа, що це підтверджує; 2) до раніше судимої особи, яка підозрюється або обвинувачується у вчиненні злочину, за який законом передбачено покарання у виді позбавлення волі на строк до трьох років, особливо у разі, якщо прокурором, крім наявності підстав, передбачених ст. 177 КПК України, буде доведено, що, перебуваючи на волі, ця особа переховувалася від органу досудового розслідування чи суду, перешкоджала кримінальному провадженню або їй повідомлено про підозру у вчиненні іншого злочину; 3) до раніше не судимої особи, яка підозрюється чи обвинувачується у вчиненні злочину, за який законом передбачено покарання у виді позбавлення волі на строк до п'яти років, - виключно у разі, якщо прокурором, крім наявності підстав, передбачених ст. 177 КПК України, буде доведено, що, перебуваючи на волі, ця особа переховувалася від органу досудового розслідування чи суду, перешкоджала кримінальному провадженню або їй повідомлено про підозру у вчиненні іншого злочину; 4) до раніше не судимої особи, яка підозрюється або обвинувачується у вчиненні злочину, за який законом передбачено покарання у виді позбавлення волі на строк понад п'ять років; 5) до раніше судимої особи, яка підозрюється або обвинувачується у вчиненні злочину, за який законом передбачено покарання у виді позбавлення волі на строк понад три роки; 6) до особи, яку розшукують компетентні органи іноземної держави за кримінальне правопорушення, у зв'язку з яким може бути вирішене питання про видачу особи (екстрадицію) такій державі для притягнення до кримінальної відповідальності або виконання вироку, в порядку і на підставах, передбачених розділом IX КПК або міжнародним договором, згода на обов' язковість якого надана Верховною Радою України [7].

Проте запобіжний захід у вигляді тримання під вартою також має часові межі. Так, відповідно до ч. 3 ст. 197 КПК України сукупний строк тримання під вартою підозрюваного, обвинуваченого під час досудового розслідування не повинен перевищувати: 1) шести місяців - у кримінальному провадженні щодо злочинів невеликої або середньої тяжкості; 2) дванадцяти місяців - у кримінальному провадженні щодо тяжких або особливо тяжких злочинів [7].

Отже, під час досудового розслідування чітко визначені часові межі тривалості застосування запобіжних заходів, що обме- 
жують конституційне право особи на свободу та особисту недоторканість, що максимально забезпечує дотримання цього права в кримінальному провадженні, захищаючи осіб від надмірного, неприпустимого примусу.

Однак, розглянувши положення ст. 315 КПК України та судову практику, можна стверджувати, що питання про порушення конституційного права особи на свободу та особисту недоторканість під час судового розгляду є проблемним та дискусійним. Порушення права особи на свободу та особисту недоторканість може бути викликане довготривалим судовим процесом за участю осіб, які перебувають під вартою чи домашнім арештом, бо максимальний строк заходів забезпечення кримінального провадження під час судового розгляду на законодавчому рівні не визначено.

Так, відповідно до ст. 315 КПК України під час підготовчого судового засідання суд за клопотанням учасників судового провадження має право обрати, змінити чи скасувати заходи забезпечення кримінального провадження, в тому числі запобіжний захід, обраний щодо обвинуваченого. За відсутності зазначених клопотань сторін кримінального провадження застосування заходів забезпечення кримінального провадження, обраних під час досудового розслідування, вважається продовженим [7].

Відповідно до п.1 ст. 6 Конвенції про захист прав людини і основоположних свобод кожен має право на справедливий і публічний розгляд його справи упродовж розумного строку незалежним і безстороннім судом, встановленим законом, який встановить обгрунтованість будь-якого висунутого проти нього кримінального обвинувачення [6].

Проаналізувавши судову практику ЕСПЛ, зокрема рішення від 10.02.2011 p. у справі «Харченко проти України» можна дійти висновку, що в Україні досить часто відбувається порушення права на свободу та особисту недоторканість саме тривалістю тримання осіб під вартою чи домашнім арештом під час судового розгляду справи. Так, основними проблемами чинного кримінального процесуального законодавства України та судової практики є порушення пп. «с» п. 1 ст. 5 Европейської конвенції з прав людини щодо періоду часу, протягом якого тримання під вартою здійснювалося без судового рішення після закінчення досудового розслідування та до початку підготовчого провадження (судового розгляду), а також щодо рішень суду, прийнятих на стадії судового розгляду, які не визначають строків подальшого тримання під вартою чи домашнього арешту, таким чином залишаючи без змін обраний на стадії досудового розслідування запобіжний захід, а не продовжуючи строк застосування такого заходу [12].

Відповідно до рішення ЕСП $А$ від 3.10.2006 р. у справі «МакКей проти Сполученого Королівства» саме визначення строків тривалості запобіжних заходів, що обмежують право особи на свободу та особисту недоторканість, полягає у запобіганні свавільному чи невиправданому позбавленню свободи [13].

Проаналізувавши практику застосування ЄСПЛ п. 3 ст. 5 Европейської конвенції 3 прав людини, зокрема рішення від 6.11.2008 р.у справі «Єлоєв проти України», рішення від 21.12.2000 р. у справі «Яблонський проти Польщі», рішення від 4.10.2001 р. у справі «ловецький проти Польщі», можна дійти висновку, що після спливу певного проміжку часу існування лише обгрунтованої підозри перестає бути підставою для позбавлення особи свободи. Також для подальшого тримання під вартою чи домашнім арештом національні суди повинні у своїх рішеннях зазначати наявність інших обгрунтованих підстав для продовження застосування таких обмежень [14].

Крім того, Конституційний Суд України ухвалив рішення від 23.11.2017 р. у справі за конституційним поданням Уповноваженого Верховної Ради України $з$ прав людини щодо відповідності Конституції України (конституційності) положення третього речення ч. 3 ст. 315 КПК України, в якому зазначено, що обгрунтованість застосування домашнього арешту та тримання під вартою має піддаватися судовому контролю через певні проміжки часу з метою перевірки наявності чи відсутності ризиків зазначених у ст. 177 КПК України, зокрема, при закінченні досудового розслідування, коли деякі ризики вже можуть зникнути та такий захід необхідно скасувати [16]. 


\section{Кримінальне право, кримінальний процес та криміналістика}

Також у рішеннях ЄСП $\lambda$ від 9.01.2003 р. у справі «Шишков проти Болгарії» та рішенні від 10.06.2008 р. у справі «Тасе проти Румунії» зазначено, що національний суд повинен обгрунтовувати період застосування запобіжних заходів незалежно від його тривалості, а автоматичне продовження строків тримання під вартою чи домашнього арешту суперечить гарантіям, встановленим у п. 3 ст. 5 Европейської конвенції з прав людини [15]. У рішенні від 10.02.2011 р. у справі «Харченко проти України» та рішенні від 15.12.2016 р.

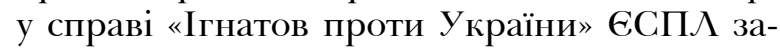
значив, що національні суди у своїх рішеннях про продовження строків тримання під вартою та домашнього арешту зазначали однакові підстави протягом всього судового розгляду справи, що 6 порушенням п. 3 ст. 5 Європейської конвенції з прав людини. Національні суди повинні зазначати інші підстави для продовження запобіжних заходів, ненаведення таких підстав порушує гарантію держави права на свободу та особисту недоторканість.

Крім того, Конституційний Суд України у своєму рішенні від 23.11. 2017 р. у справі за конституційним поданням Уповноваженого Верховної Ради України з прав людини щодо відповідності Конституції України (конституційності) положення третього речення ч. 3 ст. 315 КПК України визнав неконституційним положення цієї норми в частині автоматичного продовження заходів забезпечення кримінального провадження, обраних під час досудового розслідування. Однак, зазначена норма не була скасована на законодавчому рівні. На теперішній час це створює розбіжності в застосуванні законодавчо закріпленої норми, яка визнана неконституційною.

\section{Висновки}

Отже, враховуючи вищевикладене, кримінальні процесуальні гарантії - це визначені кримінальним процесуальним законом засоби та способи, спрямовані на реалізацію прав та обов'язків усіх суб'єктів кримінального процесу, забезпечення реалізації ї законних інтересів, а також на досягнення мети та виконання завдань кримінального судочинства. Відповідно до ст. 5 Конвенції про захист прав людини та основоположних свобод, ратифікованої Верховною Радою України 17.07.1997 р., кожен має право на свободу та особисту недоторканість. Держава зобов'язана гарантувати право на свободу та особисту недоторканість, зокрема під час здійснення кримінальної процесуальної діяльності правоохоронних органів та судів. У кримінальному процесі найчастіше обмежується права та свободи осіб, проте закріплені законом процесуальні строки тривалості застосування примусових заходів (заходів забезпечення кримінального провадження) є гарантією дотримання прав і свобод осіб, зокрема права на свободу та особисту недоторканість.

Необхідно внести зміни до ч. 3 ст.315 КПК України та викласти ії в такій редакції: «Під час підготовчого судового засідання суд за клопотанням учасників судового провадження має право обрати, змінити чи скасувати заходи забезпечення кримінального провадження, окрім запобіжних заходів, обраних щодо обвинуваченого. При розгляді таких клопотань суд додержується правил, передбачених розділом II цього Кодексу. За відсутності зазначених клопотань сторін кримінального провадження застосування заходів забезпечення кримінального провадження, окрім запобіжних заходів, обраних під час досудового розслідування, вважається продовженим. Питання продовження, скасування чи зміни запобіжного заходу щодо обвинуваченого розглядається судом незалежно від надходження клопотанъ».

Вснести зміни до ч. 3 ст. 331 КПК України шляхом доповнення іiі таким положенням: «Загальний строк тримання під вартою та стадії судового розгляду не повинен перевищувати максимальний строк покарання у вигляді позбавлення волі, який зазначений у санкції статті Кримінального кодексу України, за якою здійснюється провадження. Після перевищення зазначеного строку особа повинна бути негайно звільнена з-під варти. За клопотанням сторони обвинувачення, після спливу максимального строку тримання під вартою до обвинуваченого може бути застосовано більш м'який запобіжний захід».

\section{Аітература}

1. Алексеева А. Б., Воскобитова А. А., Давыдов В. А. Уголовно-процессуальное 
право Российской Федерации: учебник / под ред. П. А. Люпинской. М.: Юристь, 2004. $800 \mathrm{c}$.

2. Алексеева Л. Б., Давыдов В. А., Дьяченко М. С. Уголовный процесс: учебник для вузов / под ред. П. А. Аупинской. М.: Юристъ, 1995. 544 c.

3. Басков В. И., Гуценко К. Ф., Ковалев М. А. Уголовный процесс: учебник для студентов юридических вузов и факультетов / под ред. К. Ф. Гуценко. М.: Зерцало, 1997. $575 \mathrm{c}$.

4. Грошевий Ю. М., Мірошниченко Т. М., Хоматов Ю. В. Кримінальний процес України: підруч. для студентів юрид. спец. вищ. закладів освіти / за ред. Ю. М. Грошевого та В. М. Хотенця. Харків: Право, 2000. $496 \mathrm{c}$

5. Грошевий Ю. М., Тацій В. Я., Пшонка В. П. Кримінальний процес: підручник / за заг. ред. В .Я. Тація, В. П. Пшонки. Харків: Право, 2013. 824 с.

6. Конвенція про захист прав людини та основоположних свобод (1950р.), ратифікованої Верховною Радою України 17.07.1997 p. URL: https://zakon.rada.gov.ua/ laws/show/995_004.

7. Кримінальний процесуальний кодекс України: Закон України від 13.04.2012 р. № 4651-VI. URL: http://zakon3.rada.gov.ua/ laws/show/4651\%D0\%B0-17.

8. Аобойко ᄉ. Н. Уголовно-процессуальное право: учебное пособие: курс лекций. Харків: Одиссей. 2007. 672 с.

9. Маринів В. I. Принцип недоторканності особи та його нормативний зміст. Теоретичні та практичні питання реалізачй Конституиій України проблеми, досвід, перспективи»: матер. наук.-практ. конф. Харків: Право. C. 193-194.

10. Михайлов В. А., Бородин С. В., Белкин Р. С. Курс уголовного судопроизводства: общин положення уголовного судопроизводства. М.: Изд. Московского психологического социального ин-та, 2006. 824 с.

11. Рішенні ЄСПЛ від 10.06.2008 р. у справі «Тасе проти Румунії». URL: https:// zakon.rada.gov.ua/laws/show/974_433.

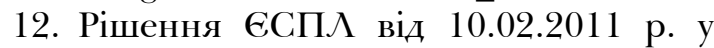
справі «Харченко проти України». URL: https://zakon.rada.gov.ua/laws/show/974_662

SUMMARY
The article analyzes the national criminal
procedural legislation on the definition of procedural
deadlines as a guarantee of respect for the right
to liberty and security of person during criminal
proceedings. It is determined that criminal procedural
guarantees should be understood as a system of legal
means and methods that ensure the implementation
of procedural rights and performance of procedural
duties by participants in criminal proceedings. It was
argued that the pre-trial investigation clearly defined
the time limits for the duration of precautionary
measures restricting a person's constitutional right to
liberty and security, which maximally enforced this
right in criminal proceedings, protecting persons from
excessive, unacceptable coercion. The author proved
that it is necessary to amend Part 3 of Article 315 and
Part 3 of Article 331 of the CPC of Ukraine.
Keywords: terms, criminalprocedural guarantees,
precautionary measures, right to liberty and security
of person.

13. Рішення ЕСП від 3 жовтня 2006 року у справі «МакКей проти Сполученого Королівства». URL: https://zakon.rada.gov.ua/ laws/show/974_662

14. Рішення ЕСП А від 6 листопада 2008 року у справі «Елоєв проти України». URL: https://zakon.rada.gov.ua/laws/show/974_433

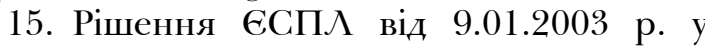
справі «Шишков проти Болгарії. URL: https://zakon.rada.gov.ua/laws/show/974_433.

16. Рішення КСУ від 23 листопада 2017 року у справі за конституційним поданням Уповноваженого Верховної Ради України 3 прав людини щодо відповідності Конституції України (конституційності) положення третього речення частини третьої статті 315 Кримінального процесуального кодексу України, режим доступу: https://zakon.rada. gov.ua/laws/show/v001p710-17.

17. Строгович М. С. Уголовный процесс: учебник. М. : Юрид. изд-во МКЮ СССР, $1941.312 \mathrm{c}$.

18. Трофименко В. М. Кримінальнопроцесуальні гарантії особистості в стадії судового розгляду: дис. ... канд. юрид. наук: 12.00.09. Харків, 2000. 188 с.

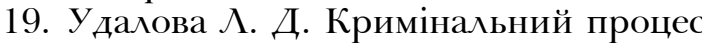
України. Загальна частина: навч. посіб. Київ: Кондор, 2005. 152 с. 